\title{
HUBUNGAN ANTARA POLA ASUH ORANGTUA DENGAN PERILAKU AGRESIF REMAJA DI SMK RISE KEDAWUNG
}

\author{
*Awis Hamid Dani ** R.Nurabdurakhman
}

\begin{abstract}
ABSTRAK
Aksi-aksi kekerasan dapat terjadi di mana saja, seperti di jalan-jalan, di sekolah, bahkan di kompleks-kompleks perumahan.Pada kalangan remaja aksi yang biasa dikenal sebagai tawuran pelajar merupakan hal yang sudah terlalu sering kita saksikan, bahkan cenderung dianggap biasa. Hal yang terjadi pada saat tawuran sebenarnya adalah salah satu contoh perilaku agresif dari seorang individu atau kelompok. Tujuan penelitian ini adalah untuk mengetahui hubungan antara pola asuh orangtua dengan perilaku agresif remaja di SMK RISE Kedawung. Metode penelitian yang digunakan adalah metoda deskriptif analitik dengan pendekatan potong silang. Populasi dalam penelitian ini adalah seluruh siswa SMK RISE Kedawung. Populasi dalam penelitian ini sebanyak 90 siswa, sampel menggunakan total populasi. Data yang digunakan adalah data primer dengan instrumen penelitian angket. Hasil dari penelitian yang dilakukan diketahui terdapat 35,6\% remaja yang berperilaku agresif di SMK RISE Kedawung. Jenis pola asuh yang paling banyak diterapkan oleh orangtua adalah pola asuh demokratis sebanyak 65,6\%. Terdapat hubungan yang signifikan antara pola asuh dengan perilaku agresif $(\mathrm{p}<0,05)$. Kesimpulan dari penelitian ini, terdapat hubungan antara pola asuh orangtua permisif dan otoriter dengan perilaku agesif remaja di SMK RISE Kedawung.
\end{abstract}

Kata Kunci : Pola Asuh Orangtua, Perilaku Agresif

\begin{abstract}
Violent act scan happened anywhere, such as in the streets, schools, even in housing. Action that commonly known for adolescent as student brawl we have often seen, and even considered as normal. The actual brawlis one of example of the aggressive behavior of anindividual or group. The purpose of this study is to identify the relation ship between parents parenting with adolescent aggressive behavior in RISE vocational high school, Cirebon. The method of this study is descriptive analytic with cross sectional approach. The population in this study were all students of SMK RISE kedawung. The population in this study were 90 students, using a sample of the total population. The datas are primary datas with questionnaire research instruments. The result of the study show that there are $35.6 \%$ adolescents who be have aggressive lyinRISEvocational high school, Cirebon. Mostly types of child care which adopted by parents is $65.6 \%$ democratic parenting. There is a significant relationshipbetween parentsparentingwithaggressivebehavior $(\mathrm{p}<0,05)$. The conclusion of this study is the existence of the relationship between permisif parenting and otoriter parenting with adolescents aggressive behavior in RISEvocational high school, Cirebon
\end{abstract}

Keywords : Parents Parenting, Aggressive Behavior

\footnotetext{
* Staf Pengajar Program Studi S1 Keperawatan STIKes Cirebon

** Staf Pengajar Program Studi D3 Keperawatan STIKes Cirebon
} 


\section{PENDAHULUAN}

Aksi aksi kekerasan dapat terjadi di mana saja, seperti di jalan-jalan, di sekolah, bahkan di kompleks kompleks perumahan.Aksi tersebut dapat berupa kekerasan verbal (mencaci maki) maupun kekerasan fisik (memukul, meninju, dan lain-lain). Pada kalangan remaja aksi yang biasa dikenal sebagai tawuran pelajar/massal merupakan hal yang sudah terlalu sering kita saksikan, bahkan cenderung dianggap biasa. Hal yang terjadi pada saat tawuran sebenarnya adalah salah satu contoh perilaku agresif dari seorang individu atau kelompok. ${ }^{1}$

Hasil survey transisi moralitas tahun 2003 yang diadakan di 10 kota besar di Indonesia menunjukkan bahwa 54\% remaja mengaku pernah berkelahi, dan $28 \%$ merasa bahwa kekerasan sebagai hal yang biasa. ${ }^{2}$ Berkowitz (1995) mendefinisikan agresi sebagai segala bentuk perilaku yang di maksudkan untuk menyakiti seseorang, baik secara fisik maupun mental. Sikap agresif merupakan penggunaan hak sendiri dengan cara melanggar hak orang lain. Kecenderungan perilaku agresi pada remaja terjadi melalui serangkaian hal yang melatar belakanginya dan diperoleh remaja saat berinteraksi dengan lingkungannya Salah satu faktor penyebab agresi yang pertama adalah frustasi.Frustasi dapat menimbulkan kemarahan dan emosi marah inilah yang dapat memicu seseorang melakukan perilaku agresif seperti perkelahian, tawuran, mencuri, memfitnah, membolos, merampok, dan lain-lain. ${ }^{3,4,5}$

Keluarga merupakan tempat interaksi pertama bagi seorang individu. Keluarga merupakan lembaga pertama dan utama dalam melaksanakan proses sosialisasi dan sivilisasi pribadi anak. Di tengah keluarga anak belajar mengenal makna cinta kasih, simpati, loyalitas, ideologi, bimbingan dan pendidikan.Keluarga memberikan pengaruh menentukan pada pembentukan watak dan kepribadian anak dan menjadi unit sosial terkecil yang memberikan fondasi primer bagi perkembangan anak. ${ }^{3,6}$

Esensi hubungan antara orang tua dengan anak sangat ditentukan oleh sikap orang tua dalam mengasuh anak, bagaimana perasaan dan apa yang dilakukan orang tua. Hal ini bercermin pada pola asuh orang tua, yakni suatu kecenderungan cara-cara yang dipilih dan dilakukan oleh orang tua dalam mengasuh anak. ${ }^{7}$

Perilaku remaja yang cukup memprihatinkan akhir-akhir ini adalah perilaku agresif.Salah satu bentuk perilaku agresif adalah perkelahian antar pelajar atau siswa. Pada tahun 2010 masyarakat Cirebon diresahkan oleh aksi geng motor yang sudah semakin brutal. Aksi geng motor ini bukan hanya kebut-kebutan dijalan, tindakan yang mereka lakukan diantaranya adalah menjarah, melakukan tindak pembunuhan, dan yang lebih memprihatinkan lagi bahwa sebagian besar anggota geng motor adalah pelajar SMA. ${ }^{8}$

Tujuan dalam penelitian ini untuk mengetahui "Hubungan Antara Pola Asuh Orangtua Dengan Perilaku Agresif Remaja Di SMK RISE Kedawung”

\section{METODE PENELITIAN}

Metode yang digunakan pada penelitian ini adalah metoda deskriptif analitik dengan pendekatan potong silang, pengumpulan data sekaligus pada suatu saat (point time approach).Populasi dalam penelitian ini adalah seluruh siswa SMK RISE Kedawung. Populasi dalam penelitian ini sebanyak 90 siswa, Pada penelitian ini pengambilan sampelnya tingkatan kelas X, XI, dan XII SMK RISE Kedawung. Banyaknya lokal kelas dari tiap tingkatan kelas X, XI dan XII adalah 6 kelas, 8 kelas, dan 8 kelas. Sehingga sampel dengan total sampel sejumlah 90 responden. Variabel terikat(dependent) pada penelitian ini adalah perilaku agresif dan variabel bebasnya adalah (independent) pola asuh orang tua, Kuesioner pola asuh orangtua adalah kuesioner yang bertujuan untuk mengungkap bagaimana perilaku yang selama ini diterima oleh remaja dari orangtua nya. Adapun aspek-aspek pola asuh orangtua meliputi: pola asuh otoriter, demokratis, dan permisif. Kuesioner perilaku agresif yang digunakan merupakan adaptasi dari Haerudin yang akan mengungkap perilaku remaja yang mengarah kepada perilaku agresif dan tidak agresif. Skala perilaku agresif ini mengacu pada pendapat yang dikemukakan oleh Mark A. Swetart, meliputi:Aggressiveness, Noncompliance, Destructiveness, dan Hostility. 
Jumlah soal dalam kuesioner ini berjumlah 48 butir yang terdiri dari 27 soal favourable dan 21 soal unfavourable.

Analisis data melalui Analisis univariabel. Uji statistik yang dilakukan pada penelitian ini yaitu uji korelasi chi kuadrat guna untuk mengukur keeratan hubungan antara dua variabel yaitu variabel bebas dan variabel terikat yang berskala nominal, dengan tingkat kepercayaan $95 \%$ dan derajat kemaknaan $\alpha: 0,05$.

HASIL PENELITIAN

Tabel 1 Distribusi Frekuensi Karakteristik Demografi remajadi SMK RISE Kedawung

\begin{tabular}{lcc}
\hline Karakteristik Demografi & \multicolumn{2}{c}{ Total } \\
\cline { 2 - 3 } & $\mathrm{f}$ & $\%$ \\
\hline Umur & & \\
$\leq 15$ tahun & 18 & 20 \\
$16-19$ tahun & 72 & 80 \\
Pendidikan Ayah & & \\
Rendah & 63 & 70 \\
Tinggi & 27 & 30 \\
Pendidikan Ibu & & \\
Rendah & 72 & 80 \\
Tinggi & 18 & 20 \\
Tipe Keluarga & & \\
Keluarga Inti & 71 & 79,9 \\
Keluarga besar & 12 & 13,3 \\
\hline
\end{tabular}

Berdasarkan tabel 1 diatas dapat dilihat bahwa mayoritas responden berusia 16-19 tahun sebanyak 72 orang $(80 \%)$, mayoritas tingkat pendidikan orangtua rendah, baik untuk ayah maupun ibu sebanyak 63 orang (70\%) untuk ayah dan 72 orang $(80 \%)$ utuk ibu, mayoritas tipe keluarga responden adalah keluarga inti sebanyak 71 orang $(79,9 \%)$.

Tabel 2 Distribusi Frekuensi Perilaku Agresif remaja diSMK RISE Kedawung

\begin{tabular}{lcc}
\hline Perilaku Agresif & F & $\%$ \\
\hline Agresif & 32 & 35,6 \\
Tidak agresif & 58 & 64,4 \\
\hline Total & 90 & 100 \\
\hline
\end{tabular}

Dari tabel 2 dapat dilihat bahwa di SMK ini terdapat 35,6\% (32 orang) remaja yang berperilaku agresif.

Tabel 3 Distribusi Frekuensi Pola Asuh Orangtua

\begin{tabular}{lcc}
\hline Pola Asuh Orangtua & $\mathrm{f}$ & $\%$ \\
\hline Otoriter & 16 & 17,8 \\
Demokratis & 59 & 65,6 \\
Permisif & 15 & 16,6 \\
\hline Total & 90 & 100 \\
\hline
\end{tabular}


Dari tabel 3 dapat dilihat bahwa jenis pola asuh yang paling banyak diterapkan oleh orangtua adalah pola asuh demokratis, sebanyak 65,6\% (59 orang).

Tabel 4 Hubungan Antara Pola Asuh Orangtua dengan Perilaku Agresif

\begin{tabular}{lcccccccc}
\hline \multirow{2}{*}{$\begin{array}{c}\text { Pola Asuh } \\
\text { Orang tua }\end{array}$} & \multicolumn{9}{c}{ Perilaku Agresif } & \multirow{2}{*}{$\begin{array}{c}\text { Total } \\
n^{2}\end{array}$} & $\begin{array}{c}\text { Nilai } \\
\text { Pvalue }\end{array}$ \\
\cline { 2 - 6 } & $\mathrm{f}$ & $\%$ & $\mathrm{f}$ & $\%$ & $\mathrm{f}$ & $\%$ & & \\
\hline Otoriter & 9 & 56,25 & 7 & 43,75 & 16 & 100 & & \\
Demokratis & 13 & 22,03 & 46 & 77,97 & 59 & 100 & 14,034 & 0,001 \\
Permisif & 10 & 66,67 & 5 & 33,33 & 15 & 100 & & \\
\hline
\end{tabular}

Dari tabel 4 dapat dilihat bahwa terdapat hubungan antara pola asuh orangtua dengan perilaku agresif remaja di SMK RISE Kedawung, dimana nilai $\mathrm{p}(0,001)<0,05$. Pola asuh yang memberikan pengaruh terbesar terhadap perilaku agresif adalah pola asuh permisif sebesar $66,67 \%$.

\section{PEMBAHASAN \\ Karakteristik demografi remaja}

Karakteritik demografi remaja di SMK RISE Kedawung dapat diketahui bahwa mayoritas remaja termasuk kelompok remaja akhir yaitu berusia 16-19 tahun, dengan tingkat pendidikan kedua orangtua yang rendah baik ibu maupun bapak, dan dengan tipe keluarga inti.

Mayoritas remaja di SMK RISE Kedawung berusia 16-19 tahun, hal ini dikarenakan banyaknya siswa pada kelas X lebih sedikit dibandingkan dengan kelas XI dan XII, sehingga sebaran usia responden terbanyak pada usia rata-rata siswa kelas XI dan XII yakni 16-19 tahun. Pendidikan kedua orangtua termasuk kedalam tingkat pendidikan rendah, dimana sebagian besar hanya tamatan SLTP. Bentuk keluarga mayoritas adalah keluarga inti dimana remaja hanya tinggal bersama ayah,ibu kakak dan ataupun adik.

\section{Perilaku agresif remaja di SMK RISE Kedawung}

Diketahui bahwa di SMK ini terdapat 35,6\% remaja yang berperialku agresif. Adanya siswa yang berperilaku agresif bisa dikarenakan usia siswa yang tergolong remaja, masa remaja merupakan masa peralihan dimana status individu tidaklah jelas dan terdapat keraguan akan peran yangharus dilakukan. Pada masa ini, remaja bukan lagi seorang anak dan juga bukan orang dewasa.

Masa remaja sebagai usia bermasalah, karena pada usia ini remaja cenderung tidak berpikir panjang dalam mengambil sebuah keputusan ataupun dalam bersikap Keinginan untuk menunjukan eksistensi dirinya dan pencarian jati diri kadang membuat mereka berperilaku 'over' yang bisa membahayakan diri mereka atau orang lain.Masa remaja sebagai ambang masa dewasa, dengan semakin mendekatnya usia kematangan yang sah, para remaja menjadi gelisah untuk meninggalkan stereotipe belasan tahun dan untuk memberikan kesan bahwa mereka sudah hampir dewasa, remaja mulaimemusatkan diri pada perilaku yang dihubungkan pada status dewasa, yaitu merokok, minum minumankeras, menggunakan obat-obatan, dan terlibat dengan perbuatan seks serta perilaku agresif. Merekamenganggap bahwa perilakuini akan memberikan citra yang mereka inginkan. ${ }^{4}$

Lokasi SMK RISE yang terletak diwilayah Cirebon, yang mana menurut teori bahwasanya kota besar seperti Jakarta, Bandung, Surabaya dan kota besar lainnya menyajikan berbagai suara, cahaya dan bermacam informasi yang besarnya sangat luar biasa. Orang secara otomatis cenderung berusaha untuk beradaptasi dengan melakukan penyesuaian diri terhadap rangsangan yang berlebihan tersebut. ${ }^{5}$

Terlalu banyak rangsangan indra dan kognitif membuat dunia menjadi sangat impersonal, artinya antara satu orang dengan orang lain tidak lagi saling mengenal atau mengetahui secara baik. 
Lebih jauh lagi, setiap individu cenderung menjadi anonim (tidak mempunyai identitas diri). Bila seseorang merasa anonim ia cenderung berperilaku semaunya sendiri salah satunya agresif, karena ia merasa tidak lagi terikat dengan norma masyarakat dan kurang bersimpati pada orang lain.Oleh karena itu letak sekolah pada penelitian ini juga dapat menjadi salah satu faktor yang mendukung adanya perilaku agresif pada siswanya. ${ }^{5}$

\section{Pola asuh orang tua}

Dapat dilihat bahwa pola asuh yang terbanyak adalah pola asuh orang tua yang demokratis, dan ada juga keluarga yang menerapkan pola asuh otoriter dan permisif.Adanya perbedaan orangtua dalam mengasuh anaknya dipengaruhi oleh tujuan atau harapan dalam mendidik anak-anak mereka. Ada dua faktor yang mempengaruhi pemilihan pola asuh orangtua terhadap anak, yaitu faktor internal dan eksternal. ${ }^{4}$

Orangtua biasanya memperlakukan anak-anak mereka sesuai dengan jenis kelaminnya.Terhadap anak perempuan mereka harus menjaga lebih ketat sehingga menggunakan pola yang otoriter.Sedang terhadap anak laki-laki cenderung lebih permisif atau demokratis. ${ }^{4}$

Pada umumnya pola asuh yang otoriter sering digunakan pada anak-anak kecil, karena mereka belum mengerti secara pasti mana yang baik dan buruk, mana yang salah dan benar, sehingga orangtua kelihatan lebih sering memaksa atau menekan. Berdasarkan penjelasan diatas dapat kita ketahui bahwa teori ini mendukung dimana lebih banyak orangtua yang menggunakan pola asuh demokratis dikarenakan usia anak mereka yang telah remaja dan mayoritas siswa di SMK adalah laki-laki, sehingga orangtua lebih memberikan kebebasan kepada anaknya dengan menggunakan pola asuh demokratis. ${ }^{4}$

\section{Hubungan antara pola asuh orangtua dan perilaku agresif remaja}

Dapat dilihat bahwa terdapat hubungan yang bermakna antara pola asuh orangtua denganperilaku agresif remaja di SMK RISE Kedawung ( $p<0,05)$. Hasil penelitian ini sejalan dengan hasil penelitian Ramli di SMAN Malang, dimana pada penelitian tersebut ditemukan adanya hubungan yang signifikan antara pola sikap orangtua dan perilaku agresif anak (remaja).Namun pola sikap demokratis memberi sumbangan yang kecil terhadap pembentukan perilaku agresif. ${ }^{1}$

Adanya perilaku agresif remaja di SMK RISE Kedawungberhubungan dengan pola asuh keluarga permisif dan otoriter, dimana pada kedua pola asuh didapatan lebih dari setengah jumlah remaja pada masing-masing pola asuh yang berperilaku agresif.

Faktor lingkungan sosial memiliki sumbangannya terhadap perkembangan perilaku individu (anak) ialah keluarga khususnya orang tua terutama padamasa awal (kanak-kanak) sampai masa remaja.Dalam mengasuh anaknya orangtua cenderung menggunakan pola asuh tertentu.Penggunaan pola asuh tertentuini memberikan sumbangan dalam mewarnai perkembangan terhadap bentukbentukperilaku sosial maupun antisosial pada anaknya.

Hasil penelitian ini sesuai dengan teori yang menyatakan bahwa pada pola asuh otoriter, di mana orangtua menerapkan aturan dan batasan yang mutlak harus ditaati, tanpa memberi kesempatan pada anak untuk berpendapat, jika anak tidak mematuhi akan diancam dan dihukum, kehangatan pola pengasuhan juga sangat rendah. Pola asuh otoriter ini dapat menimbulkan akibat hilangnya kebebasanpada anak, inisiatif dan aktivitasnya menjadi kurang, sehingga anak menjadi tidak percaya diri pada kemampuannya dan anak akan cenderung melakukan tindakan oposisi. ${ }^{3,9}$

Pada pola asuh permisif dimana orangtua memberikan kekuasaan penuh pada anak, tanpa dituntut kewajiban dan tanggung jawab, kurang kontrol terhadap perilaku anak dan orangtua hanya berperan sebagai pemberi fasilitas, serta kurang berkomunikasi dengan anak. Dalam pola asuh ini, perkembangan kepribadian anak menjadi tidak terarahdan cenderung agresif untuk meluapkan semua keinginannya karena merasa tidak ada yang melarang dan membimbing mereka. ${ }^{9}$

Sehingga dapat diambil kesimpulan bahwa pola asuh yang terlalu mengekang ataupun yang terlalau memberi kebebasan akan mempengaruhi perkembangan perilaku remaja kearah perilaku agresif. 


\section{SIMPULAN}

Berdasarkan dari hasil penelitian mengenai hubungan pola asuh orangtua terhadap perilaku agresif remaja di SMK RISE Kedawung, dapat diambil simpulan sebagai berikut:

1. Jumlah remaja yang berperilaku agresif sebanyak $35,6 \%$.

2. Jenis pola asuh yang paling banyak diterapkan oleh orangtua adalah pola asuh demokratis sebanyak $65,6 \%$.

3. Terdapat hubungan antara pola asuh orangtua permisif dan otoriter dengan perilaku agesif remaja.

\section{SARAN}

1. Berdasarkan hasil penelitian ini, diharapkan pihak sekolah dapat memberikan informasi kepada orangtua siswa mengenai perilaku anaknya, khususnya yang memiliki perilaku agresif.

2. Diharapkan kepada pihak sekolah dapat membuat aturan dan kegiatan yang dapat membatasi perilaku agresif, disarankan dengan cara memberikan skorsing terhadap siswa yang berperilaku agresif, membentuk dan mengaktifkan kegiatan-kegiatan yang bersifat positif seperti kegiatan keagamaan dan kegiatan ektra kurikuler yang lainnya.

\section{DAFTAR PUSTAKA}

1. Azwar, S. Tes Prestasi: Fungsi \& Pengembangan Prestasi BelajarEdisi Kedua. Yogyakarta: Pustaka Pelajar;2005

2. Berkowitz, L. Agresi: Sebab \& Akibatnya. Jakarta: PT Pustaka Binaman Pressindo;1995

3. Edmunds, G. \& Kendrick, D. C. The Measurement of Human Agressiveness. International Edition: John Willey \& Sans; 1980

4. Dayakisni, T. Perbedaan Intensi Prososial Siswa-siswi Ditinjau Dari Pola Asuh Orang tuaJurnal Psikologi. No 1 Tahun Ke-XVI. Yogyakarta: Fakultas Psikologi Universitas Gajah Mada;1988

5. Hurlock,E.B. Psikologi Perkembangan Anak. Edisi 6Alih Bahasa: dr. Med. Meitasari Tjandrasa. Jakarta: Penerbit Erlangga;1993

6. Hurlock,E.B. Psikologi Perkembangan (Suatu Pendekatan Sepanjang Rentang Kehidupan). Edisi 5. Jakarta: Erlangga;1994

7. Kenny. J., \& Kenny,M. Dari Bayi Sampai Dewasa. Jakarta: PT BPK Gunung Mulia;1991

8. Santrock, J. W. Life Span Development (Perkembangan Masa Hidup).Jilid 1: Edisi Kelima. Penerbit Erlangga ;2002

9. Mappiare, A. Psikologi RemajaSurabaya:Usaha Nasional;1986 